\begin{tabular}{|c|c|}
\hline $\begin{array}{l}\text { MU\%OVIL } \\
\text { MENAUEMEN } \\
\text { KEWIRAUSAHAAN }\end{array}$ & $\begin{array}{r}\text { p-ISSN 1858-1048 } \\
\text { e-ISSN 2654-9247 } \\
\text { http://ejurnal.stieipwija.ac.id/index.php/jmk } \\
\text { DOI: } \underline{\text { http://dx.doi.org/10.33370/jmk.v17i2.469 }} \\
\text { Jurnal Manajemen Kewirausahaan Vol. 17 No. 02 - Des } 2020 \\
\text { Submit: } 8 \text { Nov 2020; Review: 27 Nov 2020; Publish: } 28 \text { Des } 2020\end{array}$ \\
\hline
\end{tabular}

\title{
PENGARUH MOTIVASI, KEPEMIMPINAN, DAN KOMPETENSI TERHADAP PRODUKTIVITAS KERJA PADA BIDANG UKM ASOSIASI PENGUSAHA INDONESIA
}

\author{
(THE INFLUENCE OF MOTIVATION, LEADERSHIP, AND WORK \\ COMPETENCE TO WORK PRODUCTIVITY IN THE MIDDLE MICRO \\ BUSINESS OF THE INDONESIAN ENTREPRENEURS ASSOCIATION)
}

\author{
Oleh: \\ Cecep $^{1)}$; Miralda Indiarti2) \\ cecep_sidin@yahoo.co.id ${ }^{1)}$; miralda89@yahoo.com $\left.{ }^{2}\right)$ \\ Sekolah Tinggi Ilmu Ekonomi IPWI Jakarta1,2)
}

\begin{abstract}
ABSTRAK
Untuk mengetahui pengaruh motivasi, kepemimpinan, dan kompetensi kerja terhadap produktivitas kerja pada bidang UKM Asosiasi Pengusaha Indonesia. Pengujian instrument dengan uji validitas dan reliabilitas. Analisis data menggunakan software SPSS dengan lima tahap. Hasil penelitian menunjukkan bahwa motivasi, kepemimpinan, dan kompetensi kerja berpengaruh signifikan terhadap produktivitas kerja pada bidang UKM Asosiasi Pengusaha Indonesia. 99.9\% variasi pada produktivitas kerja ditentukan oleh motivasi, kepemimpinan, dan kompetensi kerja, sedangkan sisanya sebesar $1 \%$ ditentukan oleh faktor lain yang tidak diteliti dalam penelitian ini. Motivasi berpengaruh positif dan signifikan terhadap produktivitas kerja, artinya semakin besar motivasi maka semakin meningkat pula produktivitas kerja pada bidang UKM Asosiasi Pengusaha Indonesia. Kepemimpinan berpengaruh positif dan signifikan terhadap produktivitas kerja, artinya semakin besar kepemimpinan maka semakin meningkat pula produktivitas kerja pada bidang UKM Asosiasi Pengusaha Indonesia. Kompetensi kerja berpengaruh positif dan signifikan terhadap produktivitas kerja, artinya semakin besar kompetensi kerja maka semakin meningkat pula produktivitas kerja pada bidang UKM Asosiasi Pengusaha Indonesia.
\end{abstract}

Kata kunci: Kepemimpinan; Kompetensi; Motivasi; Produktivitas Kerja

\begin{abstract}
This research to determine influence between motivation, leadership, and work competence on work productivity in the Indonesian Entrepreneurs Association sector of UKM. Testing instruments with validity and reliability tests. Data analysis using SPSS software with five stages. The results showed that motivation, leadership, and work competence had a significant effect on work productivity in the Indonesian Entrepreneurs Association sector of UKM. Which is $99.9 \%$ variation in work productivity is determined by motivation, leadership, and work competence, while the remaining $1 \%$ is determined by other factors not examined in this study. Motivation has a positive and significant effect on work productivity, meaning that the greater the motivation, the higher the work
\end{abstract}

Jurnal Manajemen Kewirausahaan Vol. 17 No. 02 - Desember 2020

LP2M Sekolah Tinggi Ilmu Ekonomi IPWI Jakarta 
productivity in the Indonesian Entrepreneurs Association sector of UKM. Leadership has a positive and significant effect on work productivity, meaning that the greater the leadership, the higher the work productivity in the UKM sector of the Indonesian Entrepreneurs Association. Job competence has a positive and significant effect on work productivity, meaning that the greater the work competency, the higher the work productivity in the Indonesian Entrepreneurs Association sector of UKM.

Keywords: Competence; Leadership; Motivation; Work Productivity

\section{PENDAHULUAN}

$\begin{array}{ccc}\text { Suatu } & \text { perusahaan dalam } \\ \text { melaksanakan } & \text { kegiatannya, baik }\end{array}$ perusahaan yang bergerak di bidang industri, perdagangan, maupun jasa akan berusaha untuk mencapai tujuan yang telah ditetapkan sebelumnya. Satu hal yang penting yaitu bahwa keberhasilan berbagai aktivitas di dalam perusahaan dalam mencapai tujuan bukan hanya tergantung pada keunggulan teknologi, dana operasi yang tersedia, sarana, ataupun prasarana yang dimiliki, melainkan juga tergantung pada aspek sumber daya manusia.

Faktor sumber daya manusia ini merupakan elemen yang harus diperhatikan oleh perusahaan, terutama bila mengingat bahwa era perdagangan bebas akan segera dimulai, dimana iklim kompetisi yang dihadapi akan sangat berbeda. Hal ini memaksa setiap perusahaan harus dapat bekerja dengan lebih efisien, efektif dan produktif. Arti produktivitas kerja adalah kemampuan pegawai untuk menghasilkan barang atau jasa yang dilandasi oleh sikap mental yang mempunyai semangat untuk bekerja keras dan berusaha memiliki kebiasaan untuk melakukan peningkatan perbaikan (Griffin, 2004: 83).

Produktivitas kerja yang optimal merupakan cita-cita yang diinginkan perusahaan. Produktivitas berhubungan dengan masalah hasil akhir, yaitu seberapa besar hasil akhir yang diperoleh dalam proses produksi (Rosidah, 2009:247). Motivasi merupakan hal yang sangat penting untuk diperhatikan oleh pihak manajemen bila mereka menginginkan setiap karyawan dapat memberikan kontribusi positif terhadap pencapaian tujuan perusahaan. Karena dengan motivasi, seorang karyawan akan memiliki semangat yang tinggi dalam melaksanakan tugas yang dibebankan kepadanya. Adapun faktor-faktor yang mendorong untuk bertindak yaitu motivasi timbul karena dua faktor, yaitu faktor dari dalam diri manusia dan faktor dari luar diri manusia. Faktor dalam diri manusia (motivasi internal) berupa sikap, pendidikan, kepribadian, pengalaman, pengetahuan, dan cita-cita. Faktor luar diri manusia (motivasi eksternal) berupa gaya kepemimpinan atasan, dorongan atau bimbingan seseorang dan perkembangan situasi (Wursanto, 2000:131). Sekalipun seorang karyawan memiliki kemampuan operasional yang baik bila tidak memiliki motivasi dalam bekerja, hasil akhir dari pekerjaannya tidak akan memuaskan.

Selain dengan meningkatkan motivasi, juga dilakukan penilaian terhadap tingkat keberhasilan produktivitas yang telah dilakukan oleh para pegawainya melalui peran pemimpin yang cakap memimpin instansi tersebut. Kepemimpinan merupakan kekuasaan untuk mempengaruhi seseorang, baik dalam mengerjakan sesuatu atau tidak mengerjakan sesuatu, bawahan dipimpin dari bukan dengan jalan menyuruh atau mondorong dari belakang (Friska, 2004:1). Para individu/ bawahan akan mau menerima pengarahan atau kepemimpinannya terhadap kegitan dalam organisasi, apabila ada kemungkinan dipuaskannya kebutuhankebutuhan mereka (Rosidah, 2009:244). Sehingga kemampuan pemimpin dalam menggerakkan dan memberdayakan karyawan akan mempengaruhi produktivitas kerja. Pemimpin yang cakap tentunya dapat melakukan 
pantauan langsung serta mengarahkan dan memberikan masukan positif bagi karyawannya, hal ini akan memunculkan minat pegawai untuk bekerja lebih giat dan menghasilkan hasil kerja yang maksimal.

Dengan kata lain, kompetensi karyawan sangat mempengaruhi tingkat produktivitas karyawan agar lebih efisien dan efektif baik dari segi waktu dan biaya dan menjadikan karyawan tersebut agar lebih profesional dan handal pada masing-masing bidang. Kompetensi karyawan adalah mengacu pada pengetahuan (knowledge), keterampilan (skill), dan perilaku (attitude) individu yang secara langsung mempengaruhi produktivitas kerja mereka (Dessler, 2004:713).

Usaha Kecil Menengah dalam Aosiasi Pengusaha Indonesia dianggap mampu menghadapi krisis ekonomi dan memperkecil angka pengangguran yang merupakan masalah menahun perekonomian Indonesia. Karena UKM tidak membutuhkan bahan baku impor, tidak membutuhkan modal besar dan mampu menampung pengangguran dalam menjalankan usahanya.

\section{TUJUAN PENELITIAN}

Penelitian ini untuk membuktikan adanya pengaruh variabel bebas pertama motivasi, variabel bebas kedua kepemimpinan, variabel bebas ketiga kompetensi terhadap variabel terikat produktivitas kerja Bidang UKM Asosiasi Pengusaha Indonesia.

Penelitian ini juga diharapkan dapat menjadi gambaran untuk melanjutkan penelitian berikutnya khususnya dalam bidang Sumber Daya Manusia.

\section{TELAAH LITERATUR DAN PENGEMBANGAN HIPOTESIS Motivasi}

Motivasi suatu proses yang menjelaskan mengenai kekuatan, arah, dan ketekunan seseorang dalam upaya mencapai tujuan. Para individu yang termotivasi akan bertahan cukup lama dengan tugasnya untuk mencapai tujuan mereka (Robbins \& Judge, 2018:1270).
Berbicara tentang motivasi, tidak terlepas dari teori yang mendasarinya. Di antara berbagai teori tersebut ada yang membagi teori motivasi tersebut ke dalam dua macam aliran.

Pertama, Content Theories (need theories). Pada dasarnya teori ini menekankan pada pentingnya pengetahuan terhadap faktor-faktor dalam diri para bawahan yang menyebabkan mereka berperilaku. Teori ini juga mencoba menjawab tiga hal kebutuhan, yaitu kebutuhan (needs), dorongan (incentive), dan persepsi yang diperlukan oleh bawahan untuk mencapai kepuasan. Beberapa tokoh yang terkenal dengan content theory (teori kepuasan) adalah (1) psikologi Abraham Maslow dengan teori hierarki kebutuhan (2) peneliti David Mc Clelland dengan teori untuk berpartisipasi, dan (3) Frederick Herzberg dengan teori motivasi dan pemeliharaan (Mosley et al, 2006: 363).

Kedua, Process Theories (teori berdasarkan proses) ditekankan pada usaha untuk memberikan jawaban atas pertanyaan bagaimana bawahan bisa dimotivasi dan dengan tujuan apa bawahan itu dimotivasi. Beberapa tokoh terkenal antara lain Douglas Mc. Gregor dan teori X dan Y serta Victor Vroom dengan teori pengharapannya. Teori lain yang dikenal dengan hirarki kebutuhan dari Abraham Maslow (Mosley et al, 2006:164). Teori ini didasarkan pada dua prinsip: (1) kebutuhan manusia dapat tersusun dalam hirarki kepentingan dari yang terendah hingga yang tertinggi. (2) sebuah kebutuhan yang telah terpuaskan tidak lagi tepat sebagai motivator utama bagi pelakunya. Dari tingkatan ini, pemenuhan kebutuhan berjalan sesuai dengan tingkatannya (berjenjang). Selanjutnya suatu kebutuhan yang telah terpenuhi tidak menjadi motivator bagi pelakunya, kebutuhan yang belum terpenuhi yang akan menjadi motivator.

Lima tingkat kebutuhan tersebut adalah sebagai berikut: 1. Kebutuhan fisiologis (physiological or basic needs), antara lain makan, kehangatan, perlindungan, kebersihan, air, tidur, kebutuhan sexual, dan kebutuhan 
lainnya yang bersifat fisik. 2. Kebutuhan keamanan (security or safety needs), yaitu kebutuhan akan keamanan dan keselamatan jasmani dan rohani, keamanan pribadi dan keluarganya, rasa tenteram, bebas dari rasa takut, dan sebagainya. 3. Kebutuhan sosial (social needs), yaitu kebutuhan akan rasa diakui dan diterima oleh lingkungannya masyarakat, kebutuhan untuk menerima dan bekerja sama dalam kelompok (Affiliation or acceptance needs), dan kebutuhan sosial lainnya. 4. Kebutuhan harga diri (esteem or status needs), yaitu kebutuhan akan pengakuan atas status dan prestasi yang ada dan telah tercapai. 5. Kebutuhan akan aktualisasi diri (self actualization needs), yaitu kebutuhan akan perwujudan diri, pencapaian citacita diri, pembawaan sikap dirinya terhadap tugas dan kerja, dan tanggung jawabnya (Mosley et al, 2006:164).

\section{Kepemimpinan}

Kepemimpinan suatu cara seorang mempengaruhi perilaku bawahan, agar mau bekerjasama dan bekerja secara produktif untuk mencapai tujuan organisasi (Hasibuan, 2003:23). Kepemimpinan merupakan suatu kemampuan yang melekat pada diri seorang yang memimpin yang tergantung dari macam-macam faktor baik faktorfaktor intern maupun faktor-faktor ekstern (Winardi, 2000:12). Berdasarkan pengertian di atas dapat disimpulkan bahwa kepemimpinan merupakan suatu proses mempengaruhi dan mengarahkan perilaku orang lain, baik individu maupun kelompok untuk mencapai tujuan tertentu.

Dalam kepemimpinan terdapat unsur-unsur seperti pimpinan, kelompok yang dipimpin, sasaran, aktivitas, interaksi, dan kekuatan. Gaya kepemimpinan merupakan dasar dalam mengklasifikasikan tipe kepemimpinan. Sifat dan kepribadian seorang pemimpin akan banyak turut menentukan keberhasilan atau tidak tugas dan pengabdiannya. Gaya kepemimpinan adalah pola menyeluruh dari tindakan seorang pemimpin, baik yang tampak maupun yang tidak tampak oleh bawahannya (Rivai \& Mulyadi, 2004:64).
Kepribadian seorang pemimpin tidak dapat dipisahkan dengan kepemimpinannya. Setiap pemimpin mempunyai gaya kepemimpinan tersendiri, ini dikarenakan setiap pemimpin mempunyai kepribadian yang berbeda dan strategi untuk mencapai tujuan yang berbeda pula. Gaya kepemimpinan ini akan tercermin dari cara pemimpin membina dan melatih atletnya dalam meningkatkan prestasi

\section{Kompetensi Kerja}

Kompetensi dapat dibedakan menjadi tiga macam kompetensi individu, kompetensi kelompok dan kompetensi inti organisasi, yang masingmasing dapat dijelaskan sebagai berikut:

Pertama, kompetensi individu adalah kombinasi pengetahuan, kemampuan, keterampilan, dan sikap yang dimiliki karyawan sehingga ia mampu melaksanakan pekerjaan yang telah dirancang bagi dirinya baik untuk saat ini maupun di masa mendatang.

Kedua, kompetensi kelompok adalah perpaduan kompetensi-kompetensi individu dalam suatu kelompok atau unit kerja yang secara keseluruhan membentuk kekuatan sinergitik yang dapat didayagunakan uuntuk menjawab tuntutan dan tantangan pekerjaan yang dibebankan kepada kelompok. Kelompok dikatakan kompeten bila mampu melaksanakan tugas dan tanggungjawabnya sesuai seperti apa yang diharapkan.

Ketiga, kompetensi inti organisasi (company core competence) adalah keunggulan-keunggulan sinergis yang dimiliki oleh suatu organisasi atau perusahaan sehingga mampu mencapai tujuannya dan menjawab permasalahan tentang bisnis yang dihadapi (Martoyo, 2005:6).

Kompetensi adalah seorang pegawai yang mempunyai keahlian dan tanggung jawab memperbaiki dan atau memiliki kemampuan untuk menyelesaikan tugas-tugas kehidupan mereka, mengatasi kesulitan-kesulitan, serta mewujudkan aspirasi-aspirasi dan nilainilai mereka (Sutrisno, 2005:5). 


\section{Produktivitas Kerja}

Saat ini produktivitas menjadi salah satu masalah yang paling diperhatikan dalam mengembangkan perusahaan. Dengan produktivitas yang tinggi, maka perusahaan mengalami profit, sehingga pendapatan nasional juga akan naik, dan kesejahteraan nasional. Produktivitas dapat diartikan sebagai perbandingan antara keluaran (output) dengan masukan (input) (Tohardi, 2002:52). "Productivity is the measure of how well resources are brought together in organizations and utilized for eccomplishing a set of results. Productivity is reaching the highest level of performance with the least expenditure of recources". Berarti produktivitas merupakan alat ukur sejauh mana sumber daya dalam suatu organisasi diberdayakan untuk mencapai hasil. Produktivitas merupakan pencapaian titik maksimal kinerja dengan mengorbankan sumber daya seminimal mungkin (Mali dalam Sedarmayanti, 2009:23).

Produktivitas adalah perbandingan antara output (hasil) dengan input (masukan). Jika produktivitas naik ini hanya dimungkinkan oleh adanya peningkatan efisiensi dan sistem kerja, teknik produksi dan adanya peningkatan keterampilan dari tenaga kerjanya (Hasibuan, 2003:32). Dapat disimpulkan bahwa produktivitas adalah suatu hasil kerja yang diperoleh seseorang dalam berproduksi.

Dua faktor yang menentukan besar kecilnya produktivitas kerja karyawan, yaitu: 1) Kepuasan kerja karyawan yang merasa puas tentunya secara alamiah akan berupaya mengoptimalkan hasil kerja mereka (output). 2) Input, besar kecilnya input yang dimasukan dalam sebuah proses produksi akan menentukan hasil akhir (output) dari sebuah pekerjaan. Input yang dimiliki karyawan dalam bekerja antara lain motivasi, tenaga, sarana yang mendukung, pengetahuan, dan keterampilan (Yukl, 2005:54).

Ada tiga kelompok yang dapat membedakan terhadap faktor yang mempengaruhi produktivitas tersebut yaitu: 1) Faktor yang mempengaruhi produktivitas dari perekonomian atau industri-industri secara keseluruhan. 2) Faktor-faktor yang mempengaruhi produktivitas organisasi unit-unit usaha atau pabrik individual 3) Faktor-faktor produktivitas yang mempengaruhi produktivitas perseorangan. (Ravianto, 2006:52).

\section{Pengaruh Motivasi terhadap Produktivitas Kerja}

Riana Septiani dan Aryo Wahyudi meneliti Dampak Motivasi Kerja terhadap Produktivitas di PT Semen Baturaja (Persero) Tbk, Site Panjang. Berdasarkan hasil uji dan analisis data mengenai dampak motivasi terhadap produktivitas kerja karyawan PT Semen Baturaja (Persero) Tbk, Site Panjang pada departemen produksi, dapat ditarik kesimpulan sebagai berikut: a) Variabel proses administrasi dan kebijakan perusahaan berpengaruh lebih dominan terhadap produktivitas kerja dibandingkan faktor motivasi lainnya. b) Terdapat pengaruh yang signifikan antara variabel proses administrasi dan kebijakan perusahaan terhadap produktivitas kerja.

Dengan demikian, semakin tinggi motivasi kerja maka semakin meningkat juga produktivitas kerja di perusahaan. Jadi perusahaan harus memperhatikan motivasi kerja yang diberikan kepada karyawannya. Motivasi tersebut dapat berupa penghargaan terhadap prestasi kerja serta pemberian pelatihan kepada karyawan sesuai bidangnya yang dapat meningkatkan keterampilan dan kemampuan.

H1: terdapat pengaruh positif motivasi terhadap produktivitas kerja di perusahaan.

\section{Pengaruh Kepemimpinan terhadap Produktivitas Kerja}

Pengaruh Kepemimpinan terhadap Produktivitas Kerja Karyawan Bagian Multifuel Boiler pada PT Lontar Papyrus Pulp and Paper Industry, penelitian oleh Sakinah AS dan Anang Suprianto (2017). Koefisien Korelasi antara kepemimpinan terhadap produktivitas karyawan Bagian Multifuel Boiler pada PT Lontar Papyrus Pulp and Paper Industry adalah 0,878. 
Dengan demikian ada pengaruh signifikan antara kepemimpinan terhadap produktivitas karyawan Bagian Multifuel Boiler pada PT Lontar Papyrus Pulp and Paper Industry.

H2: Terdapat pengaruh positif antara variabel kepemimpinan dan variabel produktivitas kerja.

\section{Pengaruh Kompetensi Kerja terhadap Produktivitas Kerja}

Penelitian Abubakar (2018) tentang Pengaruh Kompetensi Pegawai terhadap Produktivitas Kerja Pegawai Dinas Kesehatan Kota Bandung pada Jurnal Administrasi Negara, Volume 24 Nomor 1, April 2018. Berdasarkan hasil analisis uji kontribusi pengaruh, menunjukan variabel kompetensi berpengaruh terhadap produktivitas kerja pegawai adalah sebesar 0,689 atau 68,9\%. Jadi variabel kompetensi berpengaruh positif terhadap produktivitas kerja. Kompetensi pegawai merupakan salah satu bagian penting dalam memudahkan pencapaian organisasi.

H3: Terdapat pengaruh positif variabel kompetensi pegawai terhadap produktivitas kerja.

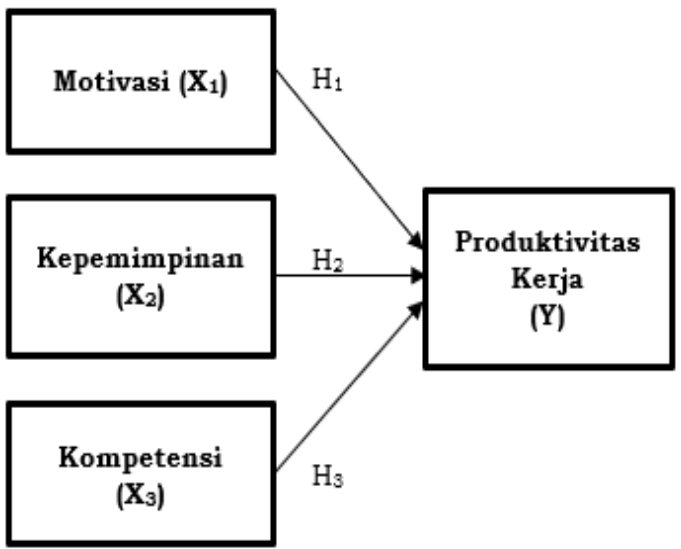

Gambar 1. Kerangka Pemikiran

\section{METODE PENELITIAN}

Obyek Penelitian adalah Asosiasi Pengusaha Indonesia unit UKM. APINDO sebagai organisasi pengusaha yang bersifat nasional menitikberatkan kegiatan pada bidang-bidang strategis yang berhubungan dengan hubungan industrial yang harmonis dan penciptaan iklim usaha yang kondusif. Kedua hal tersebut merupakan bidang sentral bagi dunia usaha.

\section{Sampel Penelitian}

Sampel penelitian yang digunakan sebanyak 35 sampel dalam lingkungan Asosiasi Pengusaha Indonesia (APINDO) yang bergerak di bidang UKM.

\section{Desain Penelitian}

Metode penelitian yang digunakan dalam penelitian ini adalah metode deskriptif dengan pendekatan survei. Metode deskriptif menurut Moh. Nazir adalah suatu metode untuk meneliti status sekelompok manusia, suatu objek, suatu set kondisi, suatu sistem pemikiran, ataupun suatu kelas peristiwa pada masa sekarang. Tujuan dari penelitian deskriptif ini adalah untuk membuat deskripsi, gambaran atau lukisan secara sistematis, faktual, dan akurat mengenai fakta-fakta, sifatsifat serta hubungan antar fenomena yang diselidiki (Nazir, 2003:54).

Metode survei adalah penyelidikan yang diadakan untuk memperoleh faktafakta dari gejala-gejala yang ada dan mencari keterangan-keterangan secara faktual, baik tentang institusi sosial, ekonomi, atau politik dari suatu kelompok ataupun suatu daerah. Metode survei membedah dan menguliti serta mengenal masalah-masalah serta mendapatkan pembenaran terhadap keadaan dan praktek-praktek yang sedang berlangsung (Nazir, 2003:56),

\section{Operasionalisasi Variabel}

Operasionalisasi variabel penelitian dapat dikemukakan sebagai berikut:

Tabel 1. Operasionalisasi Variabel

\begin{tabular}{|l|l|c|}
\hline \multicolumn{1}{|c|}{ Variabel/Konsep } & \multicolumn{1}{c|}{ Indikator } & Skala \\
\hline Motivasi (X1) & & \\
Kebutuhan yang & - Pekerjaan & \\
esensial & - Pengakuan & \\
& - Rasa memiliki & Angket \\
Kebutuhan akan & - Perhatian & $1-5$ \\
afiliasi & - Dorongan & \\
& - Finansial & \\
(Mosley et al, 2006) & - Fasilitas kerja & \\
\hline
\end{tabular}




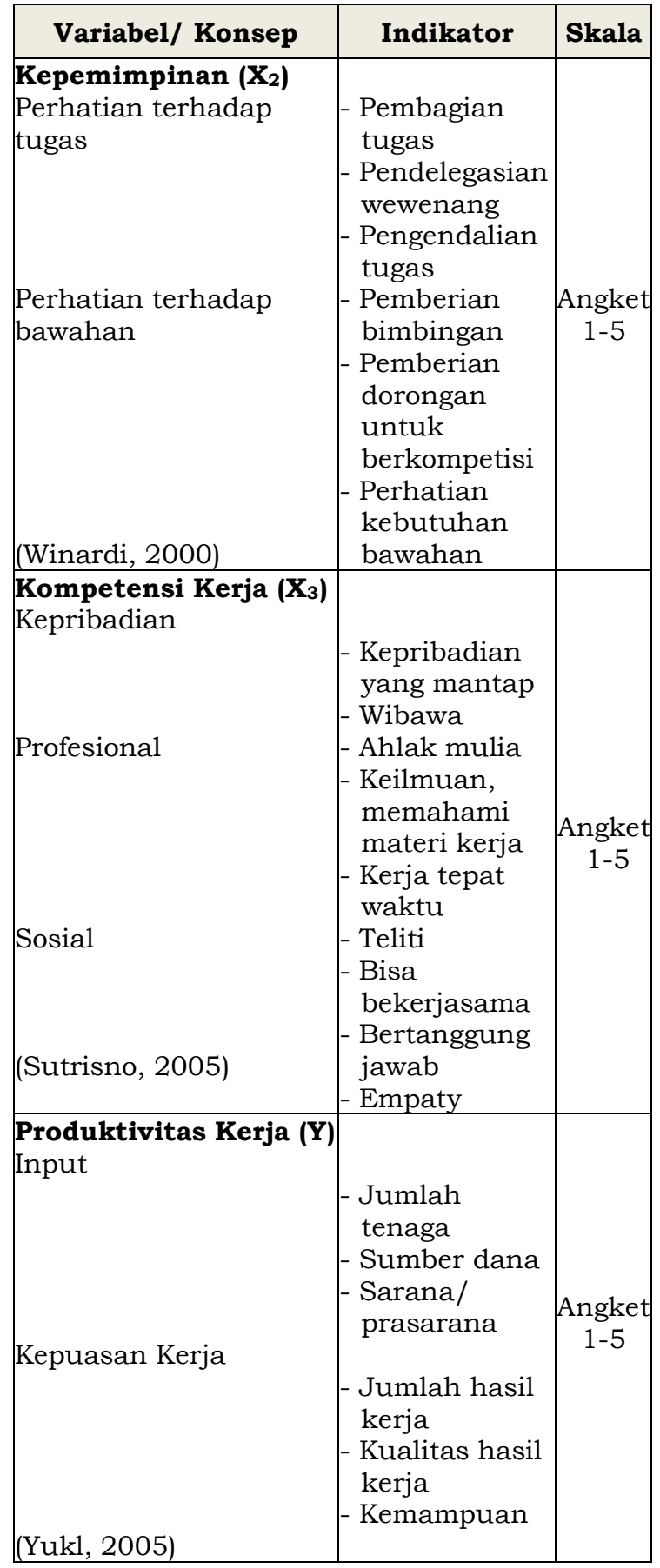

\section{Metode Analisis}

Metode analisis data kuantitatif adalah metode yang bergantung kepada kemampuan untuk menghitung data secara akurat. Selain itu, metode ini juga memerlukan kemampuan untuk menginterpretasikan data yang kompleks. Beberapa contoh metode analisis kuantitatif, seperti analisis deskriptif, regresi, dan faktor.
Pengujian instrument dengan uji validitas dan reliabilitas. Analisis data menggunakan software SPSS dengan lima tahap. Pertama, frekuensi data. Tahap kedua, pengujian kualitas data. Tahap ketiga, melakukan uji penyimpangan asumsi klasik. Tahap keempat, melakukan analisis regresi berganda. Dan tahap kelima, melakukan pengujian hipotesis.

\section{HASIL DAN PEMBAHASAN Hasil Penelitian Statistik Deskriptif}

Tujuan statistik deskriptif adalah untuk mendekripsikan variabel penelitian.

Tabel 2. Statistics

\begin{tabular}{|l|r|r|r|r|}
\hline & $\begin{array}{c}\text { Motivasi } \\
\text { (X1) }\end{array}$ & $\begin{array}{c}\text { Kepemim } \\
\text { pinan (X2) }\end{array}$ & $\begin{array}{c}\text { Kompetensi } \\
\text { Kerja (X3) }\end{array}$ & $\begin{array}{c}\text { Produktivitas } \\
\text { Kerja (Y) }\end{array}$ \\
\hline N Valid & 35 & 35 & 35 & 35 \\
Mean & 0 & 0 & 0 & 0 \\
Median & 39.7714 & 39.9429 & 41.2571 & 42.7143 \\
Mode & 40.0000 & 41.0000 & 43.0000 & 44.0000 \\
Std. Deviation & 46.88145 & 6.37524 & 7.06001 & 6.13367 \\
Variance & 23.829 & 40.644 & 49.844 & 37.622 \\
Range & 20.00 & 28.00 & 29.00 & 20.00 \\
Minimum & 30.00 & 19.00 & 20.00 & 30.00 \\
Maximum & 50.00 & 47.00 & 49.00 & 50.00 \\
Sum & 1392.00 & 1398.00 & 1444.00 & 1495.00 \\
\hline
\end{tabular}

Sumber: Data penelitian yang diolah, 2020

Output tabel di atas memberi informasi bahwa rata-rata motivasi $\left(\mathrm{X}_{1}\right)$ adalah sebesar 39.7714 dengan nilai tengah 40 dan nilai yang sering muncul adalah 36. Selain itu diperoleh standar deviasi sebesar 4.88145 dengan variance sebesar 23.829. Nilai motivasi $\left(\mathrm{X}_{1}\right)$ paling rendah sebesar 30 dan tertinggi 50 . Dari 35 sampel yang ada total motivasi $\left(\mathrm{X}_{1}\right)$ adalah sebanyak 1392 .

Rata-rata kepemimpinan $\left(\mathrm{X}_{2}\right)$ adalah sebesar 39.9429 dengan nilai tengah 41 dan nilai yang sering muncul adalah 47 . Selain itu diperoleh standar deviasi sebesar 6.37524 dengan variance sebesar 40.644. Nilai kepemimpinan $\left(\mathrm{X}_{2}\right)$ paling rendah sebesar 19 dan tertinggi 47. Dari 35 sampel yang ada total kepemimpinan $\left(\mathrm{X}_{2}\right)$ adalah sebanyak 1398.

Rata-rata kompetensi kerja $\left(\mathrm{X}_{3}\right)$ adalah sebesar 41.2571 dengan nilai 
tengah 43 dan nilai yang sering muncul adalah 49. Selain itu diperoleh standar deviasi sebesar 7.06001 dengan variance sebesar 49.844. Nilai kompetensi kerja $\left(\mathrm{X}_{3}\right)$ paling rendah sebesar 20 dan tertinggi 49. Dari 35 sampel yang ada total kompetensi kerja $\left(\mathrm{X}_{3}\right)$ adalah sebanyak 1444.

Rata-rata produktivitas kerja (Y) adalah sebesar 42.7143 dengan nilai tengah 44 dan nilai yang sering muncul adalah 50. Selain itu diperoleh standar deviasi sebesar 6.13367 dengan variance sebesar 37.622. Nilai produktivitas kerja (Y) paling rendah sebesar 30 dan tertinggi 50. Dari 35 sampel yang ada total produktivitas kerja (Y) sebanyak 1495.

\section{Uji Kelayakan Model}

Tabel 3. Model Summary ${ }^{b}$

\begin{tabular}{|c|r|r|r|r|}
\hline Model & R & R Square & $\begin{array}{r}\text { Adjusted } \\
\text { R Square }\end{array}$ & $\begin{array}{r}\text { Std. Error of } \\
\text { the Estimate }\end{array}$ \\
\hline 1 & \multicolumn{9}{|c|}{$.999^{2}$} & .999 & .999 & .23622 \\
\hline
\end{tabular}

Sumber: Data penelitian yang diolah, 2020

Dilihat dari tabel tersebut di atas yakni model summary yang menghasilkan nilai $R$ sebesar 0.999 dan sedangkan nilai Adjusted $\mathrm{R}$ Square sebesar 0.999 atau $99.9 \%$, hal ini dapat dinyatakan dengan hasil analisa secara bersama-sama variabel independen motivasi $\left(\mathrm{X}_{1}\right)$, kepemimpinan $\left(\mathrm{X}_{2}\right)$, dan kompetensi kerja $\left(\mathrm{X}_{3}\right)$ terhadap variabel dependen produktivitas kerja (Y) memiliki nilai positif dan tingkat pengaruhnya sangat tinggi, jadi ketiga variabel independen tersebut dapat saling berpengaruh terhadap variabel dependen produktivitas kerja sebesar $99.9 \%$ dan sisanya sebesar $1 \%$ disebabkan oleh faktor-faktor lain.

Tabel 4. ANOVA ${ }^{\mathrm{b}}$

\begin{tabular}{|c|c|c|c|c|c|}
\hline Model & $\begin{array}{l}\text { Sum of } \\
\text { Squartss }\end{array}$ & of & $\begin{array}{l}\text { Mean } \\
\text { Sqquarn }\end{array}$ & $\mathrm{F}$ & Sig. \\
\hline 1 Regression & 1277.413 & 3 & 425.804 & 7630.819 & $.000^{\circ}$ \\
\hline Residual & 1.730 & 31 & .056 & & \\
\hline Total & 1279.143 & 34 & & & \\
\hline
\end{tabular}

Sumber: Data penelitian yang diolah, 2020

Berdasarkan pada hasil uji ANOVA atau $F_{\text {test }}$ atau $F_{\text {hitung }}$ didapat nilai sebesar 7630.819 dimana $>$ dari $F_{\text {tabel }}(3,31)$ sebesar 2.91 dengan tingkat signifikan sebesar 0,000 karena 0,000 <0,05, maka dapat dikatakan variabel motivasi $\left(\mathrm{X}_{1}\right)$, variabel kepemimpinan $\left(\mathrm{X}_{2}\right)$, dan variabel kompetensi kerja $\left(\mathrm{X}_{3}\right)$ secara bersamasama berpengaruh sangat signifikan dengan variabel produktivitas kerja $(\mathrm{Y})$.

Hasil analisis regresi linear berganda dengan menggunakan Komputer program SPSS Versi 25 for Windows yakni analisis regresi linear berganda sebagai berikut:

Tabel 5. Analisis Regresi Linear Berganda

\begin{tabular}{|c|c|c|c|c|c|c|}
\hline \multicolumn{7}{|c|}{ Coefficients ${ }^{\mathrm{a}}$} \\
\hline \multirow{2}{*}{\multicolumn{2}{|c|}{ Model }} & \multicolumn{2}{|c|}{$\begin{array}{l}\text { Unstandardized } \\
\text { Coefficients }\end{array}$} & \multirow{2}{*}{$\begin{array}{c}\begin{array}{c}\text { Standardized } \\
\text { Coefficients }\end{array} \\
\text { Beta }\end{array}$} & \multirow[t]{2}{*}{$t$} & \multirow{2}{*}{ Sig. } \\
\hline & & B & Std: Error & & & \\
\hline & (Constant) & 2116 & 345 & & 6.135 & .002 \\
\hline & Motivasi $(X 1)$ & .042 & .012 & .034 & 3.639 & .001 \\
\hline & Kepemimpinan (X2) & .096 & .022 & .099 & 4.339 & .000 \\
\hline & Kompetensi Keria (X3) & 845 & .024 & .881 & 34.952 & .000 \\
\hline
\end{tabular}

Sumber: Data penelitian yang diolah, 2020

Untuk menentukan nilai persamaan regresi linear bergandanya sebagai berikut:

$\hat{\mathrm{Y}}=2.116+0.042 \mathrm{X}_{1}+0.096 \mathrm{X}_{2}+0.845 \mathrm{X}_{3}$

Variabel motivasi $\left(\mathrm{X}_{1}\right)$ berpengaruh positif terhadap produktivitas kerja. Variabel kepemimpinan $\left(\mathrm{X}_{2}\right)$ berpengaruh positif terhadap produktivitas kerja, meningkatnya kompetensi kerja, akan meningkatkan produktivitas kerja dengan anggapan variabel bebas lainnya tetap.

\section{Uji Hipotesis}

Untuk mengetahui apakah masingmasing variabel motivasi $\left(\mathrm{X}_{1}\right)$, kepemimpinan $\left(\mathrm{X}_{2}\right)$, dan kompetensi kerja $\left(\mathrm{X}_{3}\right)$ secara parsial terdapat pengaruh terhadap variabel produktivitas kerja (Y), maka dilakukan pengujian $t_{\text {hitung }}$ dan $t_{\text {tabel }}$. Untuk uji $t$ ini penulis melakukan dengan cara membandingkan antara hasil thitung dengan $t_{\text {tabel }}$ yaitu memiliki nilai masingmasing sebagai berikut:

Tabel 6. Hasil Uji t

\begin{tabular}{|l|c|c|c|c|}
\hline \multicolumn{1}{|c|}{ Variabel } & Nilai & thitung & $\mathbf{t}_{\text {tabel }}$ & Sig. \\
\hline Motivasi $\left(\mathrm{X}_{1}\right)$ & 0.042 & 3.639 & 1.692 & 0.001 \\
\hline $\begin{array}{l}\text { Kepemimpinan } \\
\left(\mathrm{X}_{2}\right)\end{array}$ & 0.096 & 4.339 & 1.692 & 0.000 \\
\hline $\begin{array}{l}\text { Kompetensi } \\
\text { Kerja (X3) }\end{array}$ & 0.845 & 34.952 & 1.692 & 0.000 \\
\hline
\end{tabular}

Sumber: Data penelitian yang diolah, 2020 
Berdasarkan tabel di atas diperoleh dengan nilai $t_{\text {hitung }}$ sebesar $=3.639>$ $\mathrm{t}_{0,05(33)}=1.692$, maka $\mathrm{H}_{0}$ ditolak dan $\mathrm{H}_{1}$ diterima yang berarti bahwa antara variabel motivasi $\left(\mathrm{X}_{1}\right)$ terhadap variabel produktivitas kerja $(\mathrm{Y})$ terdapat pengaruh. Dari hasil uji t tersebut di atas bahwa hipotesis yang diajukan pada bagian terdahulu ternyata mempunyai cukup bukti kebenarannya.

Dari tabel di atas diperoleh yakni karena nilai $t_{\text {hitung }}=4.339>\mathrm{t}_{0,05(33)}=$ 1.692, maka $\mathrm{H}_{0}$ ditolak dan $\mathrm{H}_{1}$ diterima yang berarti bahwa antara variabel kepemimpinan $\left(\mathrm{X}_{2}\right)$ terhadap variabel produktivitas kerja $(\mathrm{Y})$ terdapat pengaruh yang nyata dan signifikan. Dari hasil uji t tersebut di atas bahwa hipotesis yang diajukan pada bagian terdahulu ternyata mempunyai cukup bukti kebenarannya.

Dari tabel di atas diperoleh yakni karena nilai $t_{\text {hitung }}=34.952>t_{0,05(33)}=$ 1.692, maka $\mathrm{H}_{0}$ ditolak dan $\mathrm{H}_{1}$ diterima yang berarti bahwa antara variabel kompetensi kerja $\left(\mathrm{X}_{3}\right)$ terhadap variabel produktivitas kerja $(\mathrm{Y})$ terdapat pengaruh yang nyata dan signifikan. Dari hasil uji t tersebut di atas bahwa hipotesis yang diajukan pada bagian terdahulu ternyata mempunyai cukup bukti kebenarannya.

\section{Pembahasan}

Hasil penelitian menyatakan bahwa nilai Adjusted R Square sebesar 0.999 atau $99.9 \%$, hal ini dapat dinyatakan dengan hasil analisa secara bersamasama variabel independen motivasi $\left(\mathrm{X}_{1}\right)$, kepemimpinan $\left(\mathrm{X}_{2}\right)$, dan kompetensi kerja $\left(X_{3}\right)$ terhadap variabel dependen produktivitas kerja (Y) memiliki nilai positif dan tingkat pengaruhnya sangat tinggi, jadi ketiga variabel independen tersebut dapat saling berpengaruh terhadap variabel dependen produktivitas kerja sebesar $99.9 \%$ dan sisanya sebesar $1 \%$ disebabkan oleh faktor-faktor lain.

Membuktikan bahwa motivasi mempengaruhi produktivitas kerja, oleh karena itu sebaiknya pimpinan menganggap karyawan sebagai mitra, sehingga terjalin ikatan emosional yang kuat antara pemilik, manajemen, dan karyawan serta mengikutsertakan partisipasi karyawan dalam pengambilan keputusan strategik, sehubungan pencapaian tujuan organisasi.

Kepemimpinan yang ada pada Bidang UKM Asosiasi Pengusaha Indonesia terbukti mempengaruhi produktivitas kerja. Untuk itu sebaiknya pimpinan dapat berperilaku mengarahkan yang jelas, terarah dan disertai pengawasan selain itu pimpinan juga dapat berperilaku mendukung bawahan dengan melakukan pujian, mau mendengarkan keluhan karyawan dan membantu kesulitan yang dihadapi oleh bawahan. Pimpinan juga harus berusaha untuk membuat situasi dan kondisi organisasi yang stabil dan bisa membuat rasa kekeluargaan, sebab karywan akan mempunyai motivasi kerja dan berprestasi kerja jika mereka bergaul dan bekerja sama yang baik di antara mereka.

Hasil di atas juga membuktikan bahwa kompetensi kerja yang ada pada Bidang UKM Asosiasi Pengusaha Indonesia mempengaruhi produktivitas kerja, sehingga pimpinan perlu memberikan penjelasan, pengarahan, serta bimbingan bahwa pengarahan, pengaruh, dan pemahaman itu bersifat positif yang berguna untuk menciptakan rasa saling pengertian dan mempererat silaturahmi yang pada akhirnya meningkatkan hubungan kerjasama antar karyawan.

Penelitian ini sejalan dengan penelitian AS dan Suprianto (2017) bahwa ada pengaruh signifikan antara kepemimpinan terhadap produktivitas karyawan Bagian Multifuel Boiler pada PT Lontar Papyrus Pulp and Paper Industry. Penelitian ini juga mendukung hasil penelitian Abubakar (2018) bahwa variabel kompetensi berpengaruh positif terhadap produktivitas kerja pegawai.

Motivasi, kepemimpinan, dan kompetensi kerja harus sama-sama sejalan agar produktivitas kerja meningkat. Oleh karena itu karyawan harus benar-benar dapat selalu meningkatkan terus-menerus produktivitasnya dengan mengusahakan selalu hasil pekerjaan yang bermutu, teliti, dan selalu bekerja dalam team work (kerjasama) bukan sendiri-sendiri, jumlah hasil kerja selalu ditingkatkan, tidak menunda-nunda pekerjaan. Di 
samping itu, karyawan selalu mau belajar dari kekurangan sehingga mau meningkatkan.

\section{KESIMPULAN \\ Kesimpulan}

Berdasarkan analisa di atas didapat hasil bahwa terdapat pengaruh yang sangat signifikan antara motivasi, kepemimpinan, dan kompetensi kerja terhadap produktivitas kerja. Meningkatnya motivasi, kepemimpinan, dan kompetensi kerja juga meningkatkan produktivitas kerja pada bidang UKM Asosiasi Pengusaha Indonesia.

\section{Saran}

Dari kesimpulan di atas dapat diberikan saran sebagai berikut motivasi, kepemimpinan, dan kompetensi kerja harus sama-sama sejalan agar produktivitas kerja meningkat. Oleh karena itu karyawan harus benar-benar dapat selalu meningkatkan terusmenerus produktivitasnya dengan mengusahakan selalu hasil pekerjaan yang bermutu, teliti, dan selalu bekerja dalam team work (kerjasama). Untuk penelitian lebih lanjut dapat diterapkan variabel lain selain variabel-variabel di atas.

\section{DAFTAR PUSTAKA}

Abubakar, Rodlial R. T. (2018). Pengaruh Kompetensi Pegawai terhadap Produktivitas Kerja Pegawai Dinas Kesehatan Kota Bandung. Jurnal Administrasi Negara STIA LAN Makasar, 24(1), April 2018.

AS, Sakinah, \& Suprianto, Anang. (2017). Pengaruh Kepemimpinan terhadap Produktivitas Kerja Karyawan Bagian Multifuel Boiler pada PT Lontar Papyrus Pulp and Paper Industry. J-MAS, 2(1).

Dessler, G. (2004). Manajemen Personalia, Edisi 3. Terjemahan Agus Dharma. Jakarta: Erlangga.

Hasibuan, Malayu. (2003). Manajemen Sumber Daya Manusia. Jakarta: Bumi Aksara.
Martoyo, Susilo. (2005). Manajemen Sumber Daya Manusia. Yogyakarta: BPFE.

Mosley, D. C., Pietri, P. H., \& Megginson, L.C. (2006). Management Leadership in Action, Fifth Edition. New York: HaperCollins Publishers Inc.

Nazir, M. (2003). Metode Penelitian. Jakarta: Ghalia Indonesia.

Ravianto, J. (2006). Manajemen Personalia dan Sumber Daya Manusia. Yogyakarta: BPFE UGM.

Robbins, Stephen P., \& Judge, Timothy A. (2018). International Behavior. Terjemahan. Jakarta: Salemba Empat.

Rosidah, Ambar T. S. (2009). Manajemen Sumber Daya Manusia Konsep, Teori dan Pengembangan dalam Konteks Organisasi Publik. Yogyakarta: Graha Ilmu.

Sedarmayanti. (2009). Manajemen Sumber Daya Manusia dan Produktivitas Kerja. Bandung: CV. Mandar Maju.

Septiani, Riana, \& Wahyudi, Ario. (2017). Dampak Motivasi Kerja terhadap Produktivitas di PT Semen Baturaja (Persero), Tbk Site Panjang. Jurnal Ilmiah Teknik Industri, 1(1).

Sutrisno, Edy. (2005). Manajemen Sumber Daya Manusia. Jakarta: Kencana Prenada Media Group.

Tohardi, Ahmad. (2002). Pemahaman Praktis Manajemen Sumber Daya Manusia. Bandung: Mandar Maju.

Rivai, Veithzal, \& Mulyadi, Deddy. 2004. Kepemimpinan dan Perilaku Organisasi. Jakarta: PT Rajagrafindo Persada.

Winardi, J. (2000). Motivasi dan Permotivasian dalam Manajemen. Jakarta: PT Raja Grafindo Persada.

Wursanto, IG. (2000). Manajemen Kepegawaian 2. Yogyakarta: Kanisius.

Yukl, Gary. (2005). Kepemimpinan dalam Organisasi. Jakarta: Penerbit Prehalindo. 